\title{
The Development of the Civil Society and the Socialist Law-based State in Vietnam
}

\author{
Duong Xuan Ngoc
}

In the era of globalization and international integration, building the state of law has become an objective trend for every country. Vietnam, a democratic country, is not out of this general trajectory. However, from the perspective of theory and practice, the construction and perfecting of the socialist state of law in Vietnam are bringing many problems that need to be studied and resolved. This article does not intend to carry out a comprehensive study on the rule of law in Vietnam; instead, this paper tries to approach the issue from the perspective of the construction and development of civil society, an indispensable aspect reflecting the degree of completion of the state of law. It is time to be fully aware of the position and role of civil society in social development, in building and perfecting the socialist state of law.

The concept of the state of law has a long history. Nevertheless, to date, different views on the definition of the state of law are still debated. At the Berlin International Conference (September 1991) in which over 40 countries participated, a general definition was given: "The state of law is a political regime in which the state and individual have to obey the law and everyone's obligations are legally recognized and protected; all legal processes and rules are ensured by an independent court system. The state of law is obliged to respect the highest values of humanity and ensure that citizens have the ability and conditions to resist against the arbitrariness of law as well as the activities of the state apparatus. The state of law must ensure that citizens are not required to do what is out of constitution and regulations. Within the legal 
system, the constitution is supreme and must be built on the basis of freedoms and rights of citizens."

In Vietnam, the awareness of the requirements of building the state of law was first officially launched by the communist party of Vietnam in the $7^{\text {th }}$ National Party Congress:

"The National Assembly should focus on the implementation of two basic tasks: First, building the state of law, the state has the capacity to establish a synchronous legal system meeting the new requirements of social economic development and control all aspects of a civilized society; that legal system is the basis to ensure that the guidelines and policies of the party and state will be implemented effectively and is a key factor in making social relations become stronger. Second: ensuring the real power and effectiveness of the National Assembly guaranteed by the constitution."

In so far, after more than 20 years, the Vietnam Communist Party has positively realized and resolved the requirements of building and perfecting the socialist state of law. This is shown as follows:

- The objective necessity of the socialist state of law in Vietnam has been recognized and the requirements of building it have been gradually realized.

- The thinking about the socialist state of law has become deeper and changed from qualitative to quantitative. If the $7^{\text {th }}$ National Party Congress only raised the awareness of the requirements of building the state of law in Vietnam, then the nature of the socialist state of law was developed in the $8^{\text {th }}$ National Party Congress; the $10^{\text {th }}$ and the $11^{\text {th }}$ National Party Congress, the essence of the socialist state of law in Vietnam had been confirmed, i.e., the state of the people, by the people and for the people. All state power belongs to the people. Naturally, the state has no rights but authorized by the people. The state was established, not to be served by the people, but to serve the people.

- The operational mechanism of the state organs has gradually been realized, state power is unified with the assignment, coordination and control among state agencies in the implementation of the legislative, executive and judiciary. The $10^{\text {th }}$ National Party Congress confirms: "to build the operational mechanism of the socialist state of law and to ensure the principles of all state power belong to the people and state power is unified with the as-

${ }^{1}$ National Political Publishing House (2007), 340. 
signment and coordination among the bodies in the implementation of the legislative, executive and judicial; to perfect the legal system, increase the concreteness and feasibility of the provisions in legal documents; to construct, and complete checking mechanisms, monitor the constitutionality and legality of the activities and decisions of public authorities."

- Missions and principles of organization and operation of the state have been recognized and realized, i.e., the state is organized and operated under the constitution and law, the state manages the society by the constitution and law, democratic centralism is applied. The state shall respect and protect human rights and civil rights; care for happiness, the free development of the individual. The rights and obligations of citizens are stipulated by the constitution and law. People perform state power through direct democracy and representative democracy via the National Assembly, People's Council and other state agencies. The state shall respect and fully implement the international treaties in which the Socialist Republic of Vietnam is a member. The state implements the foreign policy of openness, multilateralism and diversification of international relations; Vietnam has signed and joined many international treaties and become a member of many regional and international organizations.

- The enforcement of the party's leadership of the state in the process of developing and perfecting the socialist state of law in Vietnam has been acknowledged and guaranteed.

The achievements in the perception and realization of the demands and content of building the socialist state of law in Vietnam are not in doubt. But so far, particularly in terms of theory, there are still unclear questions that need to be answered: What are the nature and characteristics of the socialist state of law in Vietnam? Is Vietnam a socialist state of law or a socialist-oriented state of law? How to understand "state power is unified"? What are the acknowledgments of assignment, coordination and control in executing state power? What are the relations between party and state within the mechanism of party leadership, state's governance and the people's mastery? What kind of mechanism is in place to ensure control and supervision rights of the people, of the Fatherland Front, the political social organizations for the activities of the state? What is the legal thinking behind building and perfecting the legal

\footnotetext{
${ }^{2}$ Communist Party of Vietnam (2006), 126.
} 
system? In particular, what is the relationship between the state of law and civil society? These concerns not only require the work of scientists but also depend on the will, capacity and commitment of all levels of the entire society.

In fact, in Vietnam, up to now, civil society has been still considered a sensitive issue and has not been formally mentioned in the party's documents. Nevertheless, from both a theoretical and a practical perspective, civil society has become a mirror and an effective measure of the degree of perfection of the socialist state of law in Vietnam. It has been a long time since the launch of the country's fundamental reform and its shift to a socialist-oriented market economy, and civil society has become a real entity confirmed and promoted in the fields of economic development, social democratization and national defense.

The development of the socialist-oriented market economy (now seen as a modern socialist-oriented and internationally integration-oriented market economy) has created an environment and conditions for the economic development of private sectors and democratization of social life. The economic actors are given more autonomy and self-responsibility as required by the market economy and law.

They are provided with more possibilities and conditions to improve their capacity to grasp development opportunities compared to the previous centralized, bureaucratic and state-subsidized economy. Thus, the socialist-oriented market economy not only creates a solid basis for the development of social organizations but also provides mechanisms to liberate resources including human resources. People are free to develop in accordance with the law and ethics and, as a result, this leads to the more active and self-confident involvement of citizens in social organizations to meet the demands and interests of individuals and thecommunity as a whole. The socialist-oriented market economy also provides more conditions for the formation and development of the civil society, i.e., the material facilities and the freedom of liberated people.

Naturally, accompanying the development of a socialist-oriented market economy is the process of building and perfecting the socialist state of law. There is a dialectical relationship between the development of a socialistoriented market economy and the building of the socialist state of law. Without the development of the socialist-oriented market economy, the requests for and the creation of material facilities to complete the socialist state of law will not be fulfilled. Vice versa, there will be no legal environment for the devel- 
opment of a socialist-oriented market economy without building and perfecting the socialist state of law. Only when a socialist-oriented market economy and a socialist state of law are developed and promoted in reality, will human rights be respected and furthered, will the civil society be formed and developed on the basis of material facilities, law and social environment. In fact, there is no perfect socialist state of law without the development of the market economy and civil society.

It can be assumed that the state of law and the civil society are two sides of the same coin. The formation and development of the state of law stem from social demands and vice versa, civil society is formed and developed on the basis of social demands and the requirements of perfecting the state of law. A socialist-oriented market economy and a socialist state of law, of the people, by the people and for the people in parallel with civil society constitute the necessary and sufficient conditions for the construction and development of the democratic society in Vietnam. The $10^{\text {th }}$ National Party Congress affirms: "to build a democratic society in which cadres, party members and civil servants should really be servants of the people; to identify the organizational forms and mechanisms for the people to exercise democratic rights in economic, political, cultural and social fields." 3

In Vietnam, social organizations have been increasingly formed. Their activities are based on the principles of self-determination, voluntariness, democracy and autonomy in funding; those organizations are playing a vital role in implementing the millennium development goals: poverty reduction and social welfare. The members of civil society help each other to reduce poverty and hunger as well as participate in charitable activities and effectively fight against social evils. These organizations share responsibilities with the state and support the state in responding to the growing demands and diversity of the members of the society while the state cannot solve or can solve, but not efficiently.

More importantly, civil organizations are also involved in monitoring and criticizing the state apparatus and the economic institutions and party organizations. At the same time, civil organizations are forums which gather opinions and demands of the people of the party and state; they also are bridges between people and party, people and the state, ensuring the democratic

\footnotetext{
${ }^{3}$ Communist Party of Vietnam (2006), 125.
} 
mechanisms of the society, e.g., "party's leadership, state's governance and the people's mastery". As a matter of fact, it is necessary to mention here that civil society is a sensitive issue; any sensitive issue may be abused and distorted which causes incalculable harm. There is no reason to avoid facing the civil society as it is an objective necessity and condition for building and perfecting the state of law as well as the socialist-oriented market economy. Therefore, simultaneously with the active construction and development of civil society, we need to struggle against the abuse and the so-called "administrative disease" in the organizations and operations of civil society.

Additionally, creatively building and developing Vietnam's civil society is seen as a revolutionary attitude that reflects an objective tendency on the one hand, and requirements of the society in creating a democratic environment for the renovation and development of the country on the other hand. Within the present context, to build and develop civil society in Vietnam to meet the requirements of an environment ensuring democratic freedoms for the people in economic development and democratic exercise, it is necessary to solve the following tasks.

Positive attitudes toward civil society should be raised, particularly, it is necessary to see civil society is not a "restricted zone" because of its sensitiveness. The success of almost 30 years of innovation has led our country to enter a new development period: economic progress, political stability, physical and spiritual life of the people has been constantly improved; the position of $\mathrm{Vi}$ etnam on the international scene was confirmed. Therefore, to further develop the success of the innovation process requires us to bravely face all the problems posed both in terms of theory and practice whether they are still a sensitive issue or not. Moreover, civil society has been existing as an entity already in our country, in the spirit of looking straight at the truth, we should have a scientific attitude towards civil society. Then, we should do research to get a better perception of civil society in terms of: its nature, characteristics, role, objective requirements and the "barrier" to building a civil society in Vietnam. Currently, the perception of a large number of Vietnamese people in general and civil servants in particular are basically limited; therefore, to raise awareness in society about civil society is a necessary and objective requirement.

The state should soon enact laws on association and other legal documents related to civil society in order to create a favorable environment for the socialist-oriented development of civil society. To build and develop civil society, 
we need to actively create the institutional system of law and compatible related systems followed by suitable mechanisms and policies for organizations and members of civil society to act in accordance with the law and that must be consistent with community interests. That means we should soon complete a legal environment for directing, managing, monitoring and adjusting the formation and operation of civil society. Like it or not, in fact, many social organizations have been created and are operating, many of which are performing very effectively and are recognized by society. However, some of them are acting less successfully and even some organizations are being exploited, consequently, the image of the civil society and the stability of the entire community are also influenced. It is now the right time to take the initiative to create a legal environment for the development of civil society; it is also needed to manage and to limit the negative issues of civil society based on strong institutions with the compatible legal system. Moreover, the promulgation of the law on associations will contribute to preventing the abuse of the sensitiveness of civil society to undermine the country's political and social stability.

It is necessary to diversify the forms of aggregation of funds for the performance of the organizations of civil society. Unlike other political organizations serving the benefit of the ruling class and financially secured by it, civil society organizations are created by their members and financed by them, the civil society should diversify the forms of aggregation and mobilization of funds for the operation. This, on the one hand, creates the material conditions for the activities of civil society organizations, and contributes to preventing the administration disease of political and social organizations on the other hand.

Party and State should have plans to train specialized staff and professionals for civil society organizations. Staff had always played a decisive role in defining success or failure of the revolution. The formation process of social and career organizations in our country in past years has been mainly spontaneous and partial. As a matter of fact, the staff of these organizations has not been trained yet; therefore, the key task now is to foster professional qualifications in order to further improve the quality of the existing staff so that they really have the ability and enthusiasm to undertake key positions in associations and unions. In the long term, to promote the role of civil society organizations, party and state should offer basic and professional training plans for managers to assure that they could serve for the long term in social organizations. By doing so, the active role of civil society can be promoted, particularly in im- 
plementing democracy, and assure the close relations between the party and the people as well as between the state and the people.

National strength must be promoted to continue pushing the renewal process, political stability and sustainable development. During the revolution, especially in the renovation period, the party has firmly seen "people as the root", "the masses who make history"; innovation must rely on the people and serve the interests of the people and be in accordance with the practice and always creative. Therefore, our party always focuses on building and strengthening the national unity bloc based on the alliance of the working class with the peasantry and the intelligentsia under the leadership of the party. Building and strengthening national unity is the revolutionary strategy of Vietnam; it is also the power source and the important factor promoting economic development and maintaining the social and political stability of the country and ensuring the success of the renewal process.

After almost 30 years of conducting the renovation, it has been reaffirmed that building and promoting the strength of the nation is always a tremendous momentum of the innovation. However, in terms of socialist-oriented economic and international integration, the foundation to build and strengthen national unity is not only in the unified target including prosperous people, a strong country, social justice, democracy, and civilization. But more important is that the party and the state must implement a national policy with these principles: ensure a fair and equal society, bring practical and legal benefits to the people; harmonize individual, collective and social interests; exercise a democracy associated with maintaining social discipline and struggle against bureaucracy, corruption and waste; constantly nurture and enhance the spirit of patriotism, the sense of national independence and territorial integrity, and the spirit of self-reliance in building the country.

In particular, it is necessary to strongly promote the role of state and government at all levels in performing the function of serving the people; constantly improve the mechanism of both direct and representative democracy; continue to improve and implement the Ordinance on Grassroots Democracy to practice the motto "People know, people discuss, people do and people check" in all types of organizations and units based on all levels and sectors, including in the party, state, Fatherland Front and mass organizations; rectify all signs of democratic violations. The promotion of democracy must be entwined with upholding the law and other social disciplines. 
The state should coordinate with the Fatherland Front and ensure necessary conditions for it and other mass organizations to have the true right to reflect thoughts and aspirations of the social strata; actively participate in developing guidelines, policies and laws; gather and mobilize people to successfully implement these policies and tasks of the state; simultaneously, monitor effectively the operations of state agencies, elected representatives, officials and civil servants in order to build and protect a clean and strong government.

Of course, at the beginning of the innovation process, based on the practice of domestic and international situation, we identified the following principles: the maintaining of socio-political stability is considered a prerequisite for any change; innovation is the method and development is the goal. And, thanks to the proper awareness and creative practice of those principles, the sociopolitical situation of the country has always been stable, the economy has developed, physical and spiritual life of the people have been significantly improved, international integration has increasingly deepened. So, in order to build and develop civil society in Vietnam, in addition to overcoming the barriers of perception and the low level of economic development that limit personal liberation and prevent building favorable conditions for the construction and development of the civil society, we should apply synchronous solutions among which a renewed perception of civil society can be seen as a key solution. More than ever before, we need to understand and act timely in the construction and development of civil society in Vietnam to pave the way for it to promote its inherent strength in the renewal period for socialism and for the happiness of the people; at the same time, we should draft strategic and specific plans for managing the activities of civil society organizations in accordance with the law in order to motivate and ensure the correct orientation for the construction and development of civil society in Vietnam.

\section{References}

Bùi Ngọc Sơn (2004): Xây dựng nhà nước pháp quyền trong bối cảnh văn hoá Việt Nam, Nxb Tư pháp. Hanoi.

Bùi Việt Hương (2006): Quan niệm về xã hội công dân trong tư tưởng chính trịphương Tây, T/C Lý luận chính trị, số 4. 
Communist Party of Vietnam (ed.) (2006): Documents of the $10^{\text {th }}$ National Party Congress. Hanoi.

Đào Trí Úc (2009): Xây dựng nhà nước pháp quyền xã hội chủ nghĩa Việt Nam trong giai đoạn hiện nay: Một số vấn đề lý luận và thực tiễn, $\mathrm{Nxb}$ Từ điển bách khoa. Hanoi.

Đỗ Văn Thắng (2006): Vấn đề xây dựng xã hội công dân ở nước ta, T/C Lý luận chính trị, số 9 .

Dương Xuân Ngọc (chủ biên) (2009): Xây dựng xã hội dân sự ở Việt Nam một số vấn đề lý luận và thực tiễn, $\mathrm{Nxb} \mathrm{CT}-\mathrm{HC}$. Hanoi. (Duong Xuan Ngoc (ed.) (2009): Constructing the Civil Society in Vietnam - Some Theoretical and Practical Issues. Hanoi.).

National Political Publishing House (ed.) (2007): Complete Documents of the Party. Vol. 51. Hanoi.

Nguyễn Am Hiểu (2006): Xã hội dân sự nhìn từ góc độ luật học, T/C Nhà nước vàpháp luật, số 12. (Nguyen Am Hieu (2006): Civil Society under the Perspective of Legal Science, Journal of State and Law, vol. 12).

Nguyễn Duy Quý (2008): Nhà nước pháp quyền xã hội chủ nghĩa Việt Nam của dân, do dân, vì dân-lý luận và thực tiễn, Nxb Chính trị quốc gia. Hanoi. (Nguyen Duy Quy (2008): The Vietnam's Socialist State of Law of the People, by the People and for the People - Theory and Practice, National Political Publishing House. Hanoi).

Nguyễn Minh Phương (2006): Vai trò của xã hội dân sự ở Việt Nam hiện nay, T/C Triết học, số 2. (Nguyen Minh Phuong (2006): The Role of the Civil Society in Vietnam Nowadays, Journal of Philosophy, vol. 2).

Trần Thành (2009): Một số vấn đề xây dựng nhà nước pháp quyền xã hội chủnghĩa ở nước ta, Nxb Chính trị quốc gia. Hanoi. (Tran Thanh (2009): Some Issues on the Construction of the Socialist State of Law in Our Country, National Political Publishing House. Hanoi.).

Vũ Duy Phú (Chủ biên) (2008): Xã hội dân sự - một số vấn đề chọn lọc, Nxb Tri thức, Hanoi. (Vu Duy Phu (ed.) (2008): The Civil Society - Some Selected Issues, Knowledge Publishing House. Hanoi). 